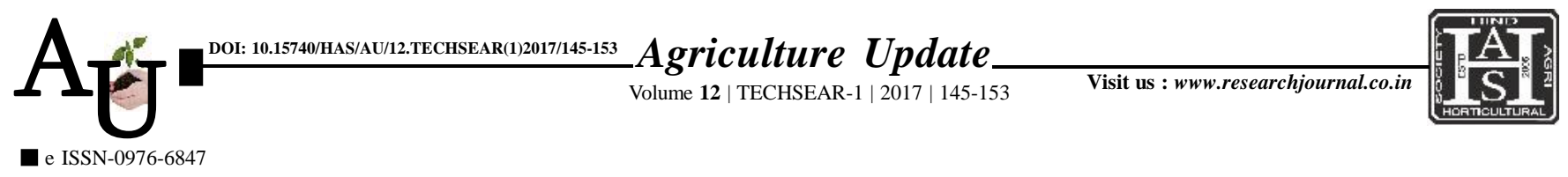

\title{
Research Article: Impact of different sources of organic manures in comparison with RDF and INM on growth, yield, system productivity, nutrient status and economics in rice- greengram cropping system
}

\section{Article Chronicle : Received : \\ 11.07.2017; \\ Accepted : \\ 26.07.2017}

KeY WoRds:

Growth parameters, Yield parameters, System productivity, Nutrient balance status, Economics, Rice-green gram cropping system

Author for correspondence :

\section{R. VENKITASWAMY}

Department of

Agronomy, Tamil Nadu Agricultural University, COIMBATORE (T.N.) INDIA

See end of the article for authors' affiliations

\section{S. ALAGAPPAN, R. VENKITASWAMY AND G. MARIAPPAN}

SUMMARY : Field experiments were carried out at Tamil Nadu Agricultural University, Coimbatore, India during Samba (August-December) season of 2012 and 2013, and summer 2013 and 2014 with rice fallow green gram to study the effect of different sources of organic manures in comparison with RDF and INM on growth, yield, economics and nutrient status in rice-green gram cropping system. The experiment consisted of fourteen treatments which were laid out in Randomized Block Design, replicated thrice and square planting with $25 \times 25 \mathrm{~cm}$ spacing was adopted during both the years experimentation. The gross return per hectare during 2012-2013, extended from Rs. 62,971 to Rs. 1,14,730 for the ricegreengram cropping system. The growth parameters such as productive tillers $\mathrm{m}^{-2}$ and the yield attributes like dry matter production, grain and straw yield of rice was recorded during both the years of the cropping system. The system productivity was worked out for the entire period of the cropping system. The nutrient balance status (N, P and $\mathrm{K}$ ) was worked out at the end of the entire cropping system. The $\mathrm{N}$ and $\mathrm{P}$ balance at the end of the cropping system was positive in all the treatments except the absolute control, whereas the negative $\mathrm{K}$ balance was worked out in the entire cropping system. Higher gross return (Rs. 1,14,730) and net return (Rs. 68,245) were associated with the INM treatment $\left(\mathrm{T}_{14}\right)$ with the grain yield of $6235 \mathrm{~kg} \mathrm{ha}^{-1}$ and it was corresponded to that observed with $\mathrm{T}_{5} v i z ., 100 \% \mathrm{RDN}$ through green manure $\left(\mathrm{T}_{5}\right)$ with the grain yield of $5084 \mathrm{~kg} \mathrm{ha}^{-1}$ for gross return (Rs. 1,12,979) and net return (Rs. 66,978). During 2013-2014, the gross return and net return of the rice-greengram cropping sequence varied from Rs. 63,817 to Rs. 1,17,175 and from Rs. 32,385 to Rs. 70,690, respectively. The INM treatment $\left(\mathrm{T}_{14}\right)$ recorded with the grain yield of $6270 \mathrm{~kg} \mathrm{ha}^{-1}$ and the higher gross return (Rs. 1,17,175) and net return (Rs. 70,690) and which was comparable with $100 \%$ RDN through green manure $\left(\mathrm{T}_{5}\right)$ with the grain yield of $5140 \mathrm{~kg} \mathrm{ha}^{-1}$ and the gross return of Rs. 1,15,380 and the net return of Rs. 69,340, respectively. The lowest gross return was registered with the absolute control $\left(\mathrm{T}_{1}\right)($ Rs. 63,817) and net return (Rs. 32,385 ) with the grain yield of 3602 and $3646 \mathrm{~kg} \mathrm{ha}^{-1}$ during the cropping sequence 2013-2014.

How to cite this article : Alagappan, S., Venkitaswamy, R. and Mariappan, G. (2017). Impact of different sources of organic manures in comparison with RDF and INM on growth, yield, system productivity, nutrient status and economics in rice- greengram cropping system. Agric. Update, 12(TECHSEAR-1) : 145-153; DOI: 10.15740/HAS/AU/12.TECHSEAR(1)2017/145-153. 